IZA DP No. 5120

Skin Tone's Decreasing Importance on Employment: Evidence from a Longitudinal Dataset, 1985-2000

Randall K. Q. Akee

Mutlu Yuksel

August 2010 


\title{
Skin Tone's Decreasing Importance on Employment: Evidence from a Longitudinal Dataset, 1985-2000
}

\author{
Randall K. Q. Akee \\ Tufts University \\ and IZA \\ Mutlu Yuksel \\ Dalhousie University \\ and IZA \\ Discussion Paper No. 5120 \\ August 2010 \\ IZA \\ P.O. Box 7240 \\ 53072 Bonn \\ Germany \\ Phone: +49-228-3894-0 \\ Fax: +49-228-3894-180 \\ E-mail: iza@iza.org
}

Any opinions expressed here are those of the author(s) and not those of IZA. Research published in this series may include views on policy, but the institute itself takes no institutional policy positions.

The Institute for the Study of Labor (IZA) in Bonn is a local and virtual international research center and a place of communication between science, politics and business. IZA is an independent nonprofit organization supported by Deutsche Post Foundation. The center is associated with the University of Bonn and offers a stimulating research environment through its international network, workshops and conferences, data service, project support, research visits and doctoral program. IZA engages in (i) original and internationally competitive research in all fields of labor economics, (ii) development of policy concepts, and (iii) dissemination of research results and concepts to the interested public.

IZA Discussion Papers often represent preliminary work and are circulated to encourage discussion. Citation of such a paper should account for its provisional character. A revised version may be available directly from the author. 
IZA Discussion Paper No. 5120

August 2010

\section{ABSTRACT}

\section{Skin Tone's Decreasing Importance on Employment: Evidence from a Longitudinal Dataset, 1985-2000*}

We investigate the effect of skin tone on employment probabilities in a longitudinal data set. Using an objective measure of skin tone from a light-spectrometer and a self-reported measure of race we find that over time the effect of skin tone on employment has diminished. These results hold both across the white and African-American samples as well as within the African-American sample itself with regard to skin tone. Further investigation indicates that all of the gains can be attributed to African-American women; there are no changes in the employment probabilities for African-American men in the 15 year panel data. We find that the expansion of employment for women is concentrated in the services occupations.

JEL Classification: J15, J16, J71

Keywords: race, gender, employment discrimination, skin tone, panel data

Corresponding author:

Mutlu Yuksel

Department of Economics

Dalhousie University

6214 University Avenue

Halifax, NS B3H $3 J 5$

Canada

E-mail: mutlu@dal.ca

\footnotetext{
* We are grateful to participants at Clark University Economics Department seminar and Aslan Akay, Joshua Angrist, Aimee Chin, Rajeev Dehejia, Tom Downes, Daniel Hamermesh, Adriana Kugler, Peter Kuhn, Linda Loury, Keith Maddox, and Emilia Simeonova for helpful discussions and valued input. Any remaining errors, omissions or oversights are ours alone.
} 
Economists have become increasingly interested in the role of skin tone and race on human capital investment and labor market outcomes. Theories of employment and wage discrimination in fully competitive markets predict that in the absence of obstacles and information asymmetries employer-based discrimination should disappear. ${ }^{1}$ In the United States, until the passage of the Civil Rights Act of 1964, firms were free to explicitly discriminate in their hiring practices by skin tone, race and gender. ${ }^{2}$ This would lead one to believe that there should be no remaining differences in wages or employment probabilities across different ethnic groups in the US. ${ }^{3}$ In reality, we observe persistent differences in labor market outcomes across ethnic and gender groups (see Goldsmith et al ,2007; Fairlie, 2009; Hersch, 2006; Neal, 2004; Mullligan and Rubinstein,2008 ).

Uncovering the reasons for these persistent differences in labor market outcomes has been an important subject of both theoretical and empirical research. Merely finding differences in labor market outcomes by skin tone or race may not be definitive proof of the continued presence of discrimination. Instead, researchers have been concerned with finding effective controls for the unobserved individual characteristics which may be highly correlated with skin tone or race. For instance, O'Neill (1990) included a measure of a pre-market characteristic into wage regressions using the Armed Forces Qualification Test (AFQT) score and found that this explained much of the Hispanic - white wage gap; Neal and Johnson (1996) find similar results for African-Americans. It is, therefore, possible that existing labor market differences across groups may be attributable to differences in unobserved characteristics or pre-market characteristics of the individual. In the analysis to follow, we will also control for unobserved individual pre-market characteristics.

\footnotetext{
${ }^{1}$ Coate and Loury (1993) provide a model with differential returns to education across groups can perpetuate instances of "statistical" discrimination.

${ }^{2}$ See Darity and Mason (1998) Table 1 for actual help-wanted advertisements from the pre-Civil Rights legislation era. These ads explicitly mention skin tone or ethnicity. In later ads, the authors go on to note, certain code words or terms are used to indicate skin tone preference. The authors discuss how even very highly skilled individuals were barred from applying for certain jobs based on their skin tone.

${ }^{3}$ Card and Krueger (1992) have shown using US Census data that the wage gap between African-American and white males has decreased from 0.40 to 0.25 from 1960 to 1980. Gottschalk (1997) finds evidence for a decrease in the wage gap for men from 1965 to 1975 and then no change afterwards. He also finds a decrease in the wage gap for women that persisted from 1973 to 1994 in his data.
} 
Our paper contributes to the literature on skin tone effects on labor market outcomes in two ways. First, we utilize a panel data set, Coronary Artery Risk in Young Adults (CARDIA), which allows us to control for time invariant individual characteristics such as childhood experiences, family background and preferences which often confounds the research on this topic. Our panel data contains a sample of young adult males and females in four US cities in six survey waves over a 15 year period. To our knowledge this is the first paper which uses such a long panel dataset to examine the role of skin tone on labor market outcomes. Second, we use an objective measure of skin tone (obtained from a light spectrometer) as well as a self-reported measure of race. Using this data, we investigate the effect of skin tone on employment probabilities over time. ${ }^{4}$ We find interesting results with respect to employment probabilities across the African-American and white groups in our sample. Our results indicate that the effect of skin tone and race on employment probability decreases over the 15 year time span in our data. We find that all of the gains are attributable to African-American women and no corresponding change for men. The effect of skin tone on female employment probabilities diminishes over time both within the African-American community as well as compared with the white community. We find a convergence in fulltime employment of African-American women with white women in our survey; employment increases from $49 \%$ at the beginning of the survey to $74 \%$ by the end which is slightly higher than the employment level for white women by the final survey year. Using information on occupational status, we find that the expansion of female employment occurs primarily in service-related occupations over this time period. There does not appear to be any increase in employment probability in the other occupational categories in the data.

The paper is organized in the following manner: the next section provides a discussion of the theories of discrimination in the labor market and previous research on this topic. Section 2 describes the empirical model employed in this analysis. The third section describes the CARDIA data set used in our analysis and details the measure of skin tone. In the fourth section we provide our empirical results and we discuss these results in the fifth section. Section 6 concludes.

\footnotetext{
${ }^{4}$ The data set does not contain information on wages or salaries for individuals. Therefore, we cannot examine the effect of skin tone on wage changes over time, unfortunately.
} 


\section{Theoretical Context and Previous Research}

In this paper we examine the effect of skin tone on employment probabilities for a sample of African-Americans and whites over time. Given the US experience with segregation based on skin tone and race and the prevalence of explicit racial discrimination in hiring practices, it is useful to examine the theoretical foundations of discrimination in the labor market. Almost forty years after the banning of discriminatory practices in the US, explaining whether skin tone or ethnic-group discrimination persists in the labor market continues to be an important area of research.

Becker (1971) described employer discrimination where an employer prefers to employ one type of worker to the exclusion of another based solely on group membership. In this scenario, the profits of non-discriminating firms should be larger over time as they can pay a lower wage for their employees; in the long-run the discriminating firms should go out of business. If there is no free-entry of (non-discriminating) firms then wage gaps may endure and the discriminating firms may not be driven out of business over time.

A second source of discrimination, known as statistical discrimination, comes from employers that have imperfect information about potential employees. Employers use a rule of thumb to evaluate potential employees based on the average attributes of their group. Coate and Loury (1993) have shown that it is possible for these perceptions about particular groups to persist and become further entrenched. In their model, individuals from a minority group face lower returns to education and consequently they will tend to underinvest in human capital thereby reinforcing the perceived stereotype. There may be a high correlation of skin tone or race with important labor market characteristics such as childhood income, parental education levels and investment in human capital. The observed differences in wages and employment may be due to these differences in pre-labor market conditions at the household level.

In their paper, Altonji and Pierret (2001), explored the possibility that firms may learn about individuals' productivity from their easily identifiable characteristics at first, but ultimately it will be their unobserved characteristics which will drive wage differences. Using longitudinal data from the NLSY, the authors find little evidence that easily observable 
characteristics such as education or even race play a long-run role in wage determination. This finding is consistent with their hypothesis that while firms may engage in statistical discrimination at first, over time, they learn about the productive qualities of individuals and that this will drive wages in the long-run. Therefore, as firms learn over time there should be a decrease in the race wage gap if race is not correlated with productivity.

Empirical research on this topic has continued to find evidence of differences in labor market outcomes by skin tone and race. There is some limited evidence that skin tone has an effect on employment probability in a static setting. Johnson et al (1995) find that darker skinned men in the same community were $52 \%$ less likely to be working than their lighter skinned counterparts in Los Angeles. Hersch (2008) finds that the there is no effect of skin tone on employment probability for immigrants using data for the US from 2003 (which is consistent with our finding that there is a reduction in the importance of skin tone on employment from 1985 to 2000). There has been no research to date that has shown the effect of skin tone over time on employment probabilities, however.

Extensive research has been conducted on the effect of skin tone on wages. Goldsmith et al (2007), using two different data sets, finds evidence of a "preference for whiteness" in wages. Individuals with lighter skin tend to earn higher wages, ceteris paribus; these results hold up both between the African-American and white communities as well as within the African-American community. In her study using similar datasets, Hersch (2006) finds that there is a big effect of skin tone on educational attainment but less evidence for an effect on wages. Fairlie (2009) uses the new ethnic and racial categories available in the 2000 U.S. Census to examine whether biracial individuals of African-American and white heritage earn wages closer to that of whites or single race African-Americans. Interestingly, he finds evidence that education levels for the biracial group is halfway between the two single race groups but the wages of the biracial group are closer to that of single race African-Americans. These recent papers indicate that using even current US data sets there is evidence for an effect of skin tone and race on wages. ${ }^{5}$

\footnotetext{
${ }^{5}$ Several other authors find evidence of the effect of skin tone or ethnic identity in other groups as well. Espino et al (2002) finds that the lighter skinned Mexican and Cuban immigrants in the US tend to have higher occupational prestige scores than their darker skinned counterparts. Arias et al (2004) finds that
} 
Other researchers have focused specifically on the role of skin tone on educational attainment in the US. Loury (2009) has shown that there have been gains in educational attainment for African-Americans over time. Specifically, she finds that the gains differ by skin tone within this group: most gains accrue to individuals with medium to light skin tones. Even after significant desegregation laws in US schools were established, there remains persistent gaps in educational attainment for darker skinned African-Americans. Gullickson (2005) also finds evidence for a lessening of the effect of skin tone effect on educational attainment over time for cohorts born after 1953. Taken together these papers suggest, at least for some segment of the African-American population, that there has been a convergence in educational levels to that of the majority white population over time.

While there appears to be some evidence for convergence in eduational attainment over time this does not appear to have translated into parity with regard to employment or wages across groups as noted previously. ${ }^{6}$ One potential explanation for this continued difference is that there are still large levels of discrimination in the labor market. A series of audit studies have provided evidence that there is a difference in job offers when individuals from different ethnic groups but otherwise similar qualifications show up for hiring interviews (Turner et al, 1991; Cross et al, 1990; Neumark, 1996). Bertrand and Mullainathan (2004) sent out resumes which differed only in their degree of ethnic-sounding names to prospective jobs. They found that the more ethnic-sounding names had fewer invitations for interviews than their similarly qualified counterparts. ${ }^{7}$ Giuliano et al (2009) have found that the hiring manager's own race appears to play a role in the hiring of retail staff - with a clear preference for their own race regardles of whether the manager is white, Hispanic or African-American. This segregation in Brazil there is evidence for a difference in the return to education by skin tone. Finally, Hersch (2008) finds that newly arrived legal immigrants to the US in 2003 are paid differently according to their skin tone. Darker skinned immigrants earn less wages, ceteris paribus.

${ }^{6}$ At least for the gender wage gap, there is some evidence that observable characteristics have played an important role in a diminshment of the difference. Blau and Kahn (1997) and O'Neill and Polachek (1993) found evidence for a closing of the male - female education gap and consequently found evidence for a narrowing of the male - female wage gap as well.

${ }^{7}$ Blau and Kahn (2006) have also concluded that occupational segregation may be responsible for differences in the gender wage gap. Goldin and Rouse (1996) have shown that blind auditions in US orchestras have tended to increase the probability of hiring a female. 
may be due to a pronounced preference for hiring individuals of one's own ethnic group. These differences in preferences can ultimately lead to segregation across occupations. Darity et al (1998) have found evidence of occupational segregation and concluded that AfricanAmerican males in particular earn 12-15\% less than their white counterparts. Bayard et al (2003) have found similar results using a different dataset for both Hispanic and AfricanAmerican men and women. The authors conclude that occupational segregation may account for $1 / 3$ to $1 / 2$ of the wage gap for African-American men. Juhn $(1992,2003)$ has shown that a large amount of African-American men have increasingly become disconnected from the formal labor market and including these individuals in typical calculations would tend to moderate the gains in the wage gap over time across African-Americans and whites. Neal (2004) finds that while there are persistent gaps in wages across the two groups, these gaps may in fact be too small if selection into labor force participation is not accounted for. Specifically, there may be individuals in the African-American community that are increasingly separated from the formal labor market, accounting for these individuals and their characteristics would tend to increase the wage gap. He finds a larger wage gap between African-American men and white men than for women. ${ }^{8}$

Similar to previous researchers, we are interested in determining whether the effect of skin tone on labor market outcomes has an effect. However, because we have panel data, we can look at the effect of skin tone on employment over time. Additionally, the panel structure of our data allows us to control for household and cultural characteristics that are fixed over time. These unobserved fixed effects have often confounded previous research using cross-sectional data. Therefore, our main focus is on the effect of skin tone and race on employment probability over time holding pre-labor market conditions constant for individuals over time. Loury (2009) and Gullickson (2005) have found that there is a reduction in the importance of skin tone on education over time in the US which leads us to expect to find a similar outcome with respect to employment probabilities in our sample. Our framework will allow us to detect whether there has been a divergence, convergence or

\footnotetext{
${ }^{8}$ Mulligan and Rubinstein(2005) find similar results for the gender wage gap. Accounting for the positive selection of women into the labor force over time, the authors find that the median woman still earns less than the median male.
} 
no change in employment probabilities by skin tone over time.

\section{Empirical Specifications}

In the regressions to follow, we employ fixed-effects regression models to account for the potential unobserved heterogeneity at the individual level. The regression equations that we employ are the following:

(1) Employment $_{i t}=\alpha_{1 i}+\alpha_{2 t}+X \beta+$ Black $\times$ Year $1 \times \delta_{1}+\ldots+$ Black $\times$ Year $5 \times \delta_{5}+\varepsilon_{i t}$

(2) Employment $_{i t}=\alpha_{1 i}+\alpha_{2 t}+X \beta+$ SkinTone $\times$ Year $1 \times \delta_{1}+\ldots+$ SkinTone $\times$ Year $5 \times$ $\delta_{5}+\varepsilon_{i t}$

In the first equation, we use a simple indicator variable, Black, which is self-reported in the data. The indicator variable is interacted with a year variable and each coefficient indicates how being black (African-American), ceteris paribus, affects employment probabilities for each survey year relative to the most current year, 2000.

The second equation uses a continuous variable for skin tone which ranges in values from 43 to 96 , where higher numbers indicate darker skin tone. The skin tone variable is interacted with a survey year indicator variable and these five variables are included in the regression above. Each coefficient indicates how different skin tones affect the probability of employment opportunity at different points in time relative to the final survey year 2000 .

Employment is a simple indicator variable which takes on values of 1 when an individual is employed full-time in our data and a value of zero otherwise. ${ }^{9}$ The vector $\mathrm{X}$ controls for time variant characteristics such as age, household size, whether there are household children, the respondent's current school status, and marital status. Time invariant characteristics such as gender or race are controlled for by the fixed effects variable, $\alpha_{1 t}$. Additionally, the individual fixed effect controls for other unobserved childhood characteristics and preferences. We employ a linear probability model with fixed-effects. Models with bootstraped standard errors provide qualitatively similar results. Additionally, a fixed-effects logit model provided qualitatively similar results.

\footnotetext{
${ }^{9}$ Alternative measures of employment, which include full and part-time employment, provide qualitatively similar results.
} 


\section{Data and Descriptive Statistics}

The CARDIA data is a longitudinal data set initiated in 1985 in four US cities: Birmingham, Alabama; Oakland, California: Minneapolis, Minnesota and Chicago, Illinois. A cohort of 5115 men and women were recruited and were followed for the next 15 years until 2000. The age of the cohorts at intake ranged from 18 to 30 years old; samples were collected to get a balance on age, gender, education and race; by the final survey year, 2000, these individuals ranged in age from 32 to 45 years. The data was primarily for use in a long-run health study on cardiovascular health. ${ }^{10}$ For our purposes, however, additional human capital and employment variables were collected and available for analysis. ${ }^{11}$

There were six survey waves conducted in the following years: 1985, 1986, 1990, 1992, 1995, 2000. Self-reported ethnic classifications were collected in each survey wave. In the fourth survey wave (1992), however, the researchers took a light spectrometer reading of the skin tone of survey participants. These spectrometers provide an additional, and objective, measure of skin tone. Figure 1 provides a graph of the distribution of skin tone for both the white and African-American subsamples. ${ }^{12}$

\footnotetext{
${ }^{10}$ For a fuller description of the survey methodology, see Friedman GD, Cutter GR, Donahue RP, Hughes GH, Hulley SB, Jacobs DR, Jr, Liu K, Savage PJ. CARDIA: Study design, recruitment and some characteristics of the examined subjects. Journal of Clinical Epidemiology. 1988; 41(11):1105-1116. PMID: 3204420 .

${ }^{11}$ There is a public use data, which is available via the following website: http://www.cardia.dopm.uab.edu/index.htm

${ }^{12}$ The light spectrometer measures the percent of light reflected back; therefore the range of values is between 0 and 100 . We have recoded the values so that higher numbers indicate darker skin tone. For the purposes of our study, we use the amber measure as this is the commonly used measure. Measures are taken on the underside of an individual's upper arm so that it is the area that has the least long-term variation in skin tone. Halder et al (2003) indicate that ethnic skin tone tends to get darker over time; but this starts after 50 years of age which is outside our survey ages. Additionally, we find it highly unlikely that a large proportion of our sample would change their skin tones in a sustained manner over a long period of time. For instance, de Souza (2008) discusses skin bleaching in Africa and the long-run health consequences. The occurrence of skin bleaching in the United States is low; but there are no large scale studies on the topic. Skin bleaching appears to be a much bigger issue in developing countries such as India, the Phillipines and the countries of sub-Saharan Africa.
} 
Additionally, we use other data such as age, educational attainment, household size, whether there are any children in the household, the individual's current school attendance status and marital status. Our measure of education measures the highest level of education attained by the survey date and is divided into the following five dummy variables: less than a high school education, a high school diploma, an associate's degree, a bachelor's degree, a doctorate degree. For our regressions that follow, we take less than a high school education as the reference category.

We use a balanced panel for our analysis that follows; individuals in our analysis are present in all survey years. We find that the female employment probabilities from the balanced panel approximate the general trends found in the US as a whole over this time period. Specifically, in Figure 2, we find that African-American women tend to increase their employment probability over time, while there is little or no change for white women in the period 1985 to $2000 .^{13}$ In Figure 3, we provide the general trend for employment probability for men in the same time period. We find that the difference in employment probability is constant over time for men across the two racial groups. This is inconsistent with previous research (Juhn, 1992; 2003; Holzer et al, 2005; Borjas et al, 2009) which has found a strong divergence in employment probabilities; African-American men have had a steady decline in labor force participation over time. Examining our data, we find that African-American males are also the most likely to be missing from future survey waves. If we code these missing observations as out of the labor force then we are able to produce employment probabilities over time that reflect the general employment trend for the US. Figure 4 provides these results where there is a clear decline in African-American employment for males and little or no change for white males. Therefore, in our balanced panel and the results to follow we conclude that our findings apply to the subset of men who have a higher probability of being employed (and consequently included in our data) over time. We expect that the results for women are probably closer to the true effect of skin tone on employment probability over time.

We present the survey means for our balanced panel by race in Table 1 over all panel

\footnotetext{
${ }^{13}$ Using data from the 1980, 1990 and 2000 US Census, we find that there is a similar trend for adult females in the US.
} 
years. The white sample is more likely to be full-time employed than the African American sample and about one year older. The white sample has higher levels of human capital than the African-American sample; fully $40 \%$ of the sample observations have a bachelor's degree while over $60 \%$ of the African-American sample has a high school diploma or less. The African-Americans in this sample are more likely to be married than their white counterparts and have slightly more children. Household sizes appear to be approximately the same across the two groups. Finally, the average skin tone for whites is 53 while it is 78 for African-Americans.

\section{Empirical Results}

\section{A Regression Results for Complete Sample}

In order to account for the potential correlation between race and other unmeasured time invariant characteristics, we employ a fixed-effects regression for our panel data. We first investigate whether being African-American has an effect on employment probabilities for our total sample. In Table 2, we provide the results from the simple analysis of race and skin tone on employment probabilities. As this is a fixed-effect regression, we do not include the simple indicator variable of race as that is part of the fixed-effect which is already being controlled. Instead, we employ an interaction variable for race and a year interaction effect. This variable is intended to measure the effect of identifying as African-American on employment at each survey year. We have included five of these interaction terms with the final survey year serving as the reference category. Our findings here indicate that conditional on the other covariates, the effect of African-American identity on employment is at first negative and statistically significant. In the first year, African-American identity reduces the probability of full-time employment, ceteris paribus, by over $14 \%$ which is quite a large amount given that only $70 \%$ of the sample is full-time employed. However, this negative effect diminishes in magnitude and statistical significance in the subsequent survey waves. We interpret this as evidence that the effect of race has diminished in relation to employment probabilities for our sample. In our analysis we are using a balanced panel, we have found that the results 
are stronger if we use the unbalanced panel.

The additional covariates in this regression are of the expected signs and magnitude. The coefficient on age is positive but not statistically significant; as the range in ages is only 12 years, it is not surprising that these results are not strong. The education dummy variables indicate that highly educated people are likely to be employed relative to individuals with less than a high school diploma. The coefficient on whether a person is currently in school has a negative sign as we would expect; individuals who are enrolled in school are much less likely to be full-time employed. ${ }^{14}$ We find no significant effect of marital status on employment probabilities; however, we find strongly negative effects of household size and the presence of any children in the household on employment probabilities.

The second column in this table repeats the analysis described above using instead an interaction variable of skin tone and survey year. In the first year, an increase in skin tone of one standard deviation (13 points on the light spectrometer measure) results in a reduction in the probability of employment by almost $7 \%$. The size of the effect of skin tone decreases over time; by the fifth survey year the effect of an increase in skin tone of one standard deviation only reduces the probability of employment by $2.6 \%$ relative to the sixth survey year. The results are similar those found using the race variable. In fact, in the third column, we include both the skin tone-year interaction variables and the race-year interaction variables and we find that the skin tone-year interaction coefficients are the only ones which are statistically significant. This may indicate that the race-year interaction variables are just a proxy for skin tone. ${ }^{15}$

\section{B Regression Results by Race}

In the results above, we found that the effect of skin tone appears to be lessening over time for the full sample. In this section, we divide the sample between the white and AfricanAmerican respondents. Table 3 provides the analysis for the African-American sample. In

\footnotetext{
${ }^{14}$ The results are robust to omitting individuals who are currently in school as well.

${ }^{15}$ We find additional evidence for this by restricting the sample just to the region where there is an overlap of skin tones (in the range 60-70) for both ethnic groups, we find that the ethnic indicator is not statistically significant at all.
} 
the first column, the regression indicates that the effect of skin tone, even within the AfricanAmerican group, has been diminishing in size and statistical significance over time relative to final survey year. In the first column, we examine the total African-American sample. The effect of an increase in skin tone of one standard deviation ( 7 points on the light spectrometer measure for this sub-sample) results in reduction in employment probabilities of almost $3 \%$; this coefficient is only statistically significant at the $10 \%$ level. The effect of skin tone is not statistically significant in the other survey years.

When we divide our sample of African-Americans by gender, we find that there are differential results within these two smaller sub-groups. For men, there is no difference in the effect of skin tone on employment probabilities over time; none of the skin toneyear interaction coefficients are statistically significant in Table 3 column 2 . We find that married men appear to have a higher likelihood of employment compared to their unmarried counterparts. The estimated coefficient on marital status is twice as large as it is for white men in Table 4 column 2. This perhaps indicates that marital status serves as an additional indicator of labor market attractiveness for potential employers of African-American men.

In the third column of Table 3, we examine the subset of African-American women. The skin tone-year interactions are large in magnitude and statistically significant. We find that an increase in skin tone of one standard deviation results in reduction of employment probability of women of about $4.3 \%$ in the first survey year relative to the last survey year. By the fifth survey year, this effect had diminished in size and statistical significance to only about half that original amount to $2.1 \%$. Overall these findings indicate that, conditional on the other individual characteristics, there is evidence of convergence in employment probabilities for African-American women of various different skin tones. We find no evidence for the effect of marital status on the employment probability. This is in stark contrast to that of white women in Table 4 . In those results, white married women are more likely not to be full-time employed. This mirrors other results noted by Neal (2004).

Table 4 replicates the analysis for the white sample. In the first column, we examine the role of skin tone for the entire white sample and find no conclusive results with regard to skin tone-year interactions. The second and third columns provide the analysis for the male and female subsamples respectively. Once again, there does not appear to be any consistent 
results with regard to the effect of skin tone-year interaction effects over time. This is strong evidence that the initial results found in Table 2 are due almost exclusively to improvements in the employment probabilities of African-American women in our data.

\section{Regression Results by Race and Gender}

In this section, we analyze the effect of skin tone on employment probability by gender. Table 5 provides the results for women alone (inclusive of both white and African-American). The results indicate that in the first two survey years there is a large effect of skin tone on employment probabilities. An increase in skin tone of one standard deviation (13 points on the light spectrometer measure) results in a reduction in employment probability of almost $10 \%$. In the next three survey years, the effect of skin tone diminishes in size and a corresponding increase in skin tone of one standard deviation is only associated with a reduction in employment probability of about $5 \%$. These results are robust to the inclusion of the race-year interaction variables as well. In Table 6 we restrict the analysis to the men. We do not find any results with regard to changes in the effect of skin tone-year interaction effects on male employment probability over time.

Overall the results from this analysis seems to indicate that there has been no change in the role of skin tone on male employment probabilities over time. However, there appears to be conclusive evidence that effect of skin tone on employment has been decreasing for AfricanAmerican women both in comparison to white women and within the African-American sample. Using the National Survey of Black Americans, survey years 1979-1980 and 19871988, and the Multi-City Survey of Urban Inequality in 1992 we find that there is no evidence in these data sets to indicate that the results are driven by an aging effect over this time period. ${ }^{16}$ We take this to mean that the role of skin tone for women has decreased for our sample in the years 1985-2000.

While we find no results for men, this does not appear to be due to the use of our balanced

\footnotetext{
16 Appendix Tables I and II provide the results for the National Survey of Black Americans,an interaction effect between skin tone and age cohorts. The results for the Multi-City Survey of Urban Inequality are presented in Appendix Table III, and indicate that there is no difference with regard to employment for African-American women by skin tone and age cohorts.
} 
panel nor due to the selective attrition in our data. African-American men are less likely to be present in all survey waves; they have much higher rates of attrition than the other three groups. As discussed previously, we have found that the employment probabilities remain roughly constant over time between the two ethnic groups for men which is inconsistent with previous findings. If we assign the missing individuals (in the unbalanced panel) as out of the labor force, we are able to approximate the divergence in employment probability observed in US census data. When we run the analysis above including the missing observations for African-American men as out of the labor force, we continue to find no results for the effect of skin tone on employment probabilities over time. ${ }^{17}$

\section{Discussion of Potential Mechanisms}

Our primary results indicate that there is a decrease in the effect of skin tone on the employment probabilities of African-American women; no comparable results occur for AfricanAmerican men. We attempt to explore a few of the potential explanations for our observed results.

\section{A. Changes in Welfare Program and Labor Supply of Women}

One potential explanation may be the significant changes to the US welfare program in the late 1990s. This mechanism is a labor supply one and for this to be driving our results, it would require that the reform would have had to have affected the employment probabilities of African-American women significantly more than for white women. Potentially this could be the case if there were very little or no white women on welfare. Unfortunately, the data does not provide any direct information on whether an individual receives welfare in this data set.

Instead, we separate our sample of women into two further subgroups: married women and single women. The specific changes of the welfare reform after the 1996 reform propelled individuals on welfare to work. A woman is much more likely to be on welfare if she is single.

\footnotetext{
${ }^{17}$ As an additional robustness check, we code all African American men with missing observations as employed. The results do not change significantly from previous analysis; the effect of skin tone does not appear to affect employment probabilities for men in this sample.
} 
Therefore, we examine whether our results from Table 5 are being driven by a movement of single women (who have a higher probability of being on welfare) into employment due to changes in welfare. Our results in Table 7 indicate that our results are not driven by single women. In fact, the results are found to be strongest in the married subsample. Therefore, we conclude that welfare reform, while a potential explanation for changes in African-American female employment over time, does not appear to be driving our results.

\section{B. Changes in Labor Demand for Service Occupations}

The CARDIA dataset provides some limited information on the occupational status of individuals. In this section, we examine whether there are certain occupations which are responsible for this expansion of employment for African-American women. For the first five survey waves, the CARDIA data provides information on occupation at the one-digit level. ${ }^{18}$ The five occupational categories available are professional, sales, services, precision production and general labor. Table 8 provides results the estimated coefficients from the skin tone-year interactions for each of the six occupational categories in the data by gender. The results indicate that the effect of skin tone-year interactions are decreasing over time for female employment in the services industries. It appears that African-American women are finding increased employment opportunities in service occupations over time; it is this movement into service occupations that is responsible for the reduction in skin tone effects on employment in our data. We find no other change in occupations for the male or female subsamples.

A possible explanation of this observed movement into service occupation comes from research that examines the differential rate of employment expansion in the US from 1980 onward. Autor and Dorn (2009) have found significant evidence that technological change in the US, primarily automation of middle-skill tasks, has led to job growth in high skilled occupations and in low-skilled service occupations; employment in service occupations increased by $11 \%$ from 1980 to 2005 while it decreased for other occupations such as production, laborers, farming. Only managers and professional occupations enjoyed a similar expansion in employment at $10.3 \%$ over this same time period. The authors explain that service

\footnotetext{
${ }^{18}$ The sixth survey wave contains information about occupational at the three digit level, but was not used in this analysis.
} 
occupations have expanded as these tasks have been difficult, if not impossible, to automate.

Given the increase in labor demand for service occupations over time, we find an increased inflow of African-American women into these occupations. Examining the employment probabilities for women by race across all survey waves, we find that for white women there is virtually no change in employment probabilities over time (remaining in the low $60 \%$ on average). While there is a large increase in employment probabilities for African-American women in the same time period. Table 9 shows these results. The employment probability of African-American women converges and surpasses that of white women in this time period.

We believe that as labor demand increased from the 1980's onward for service occupations and the supply of white female employees neared the full-employment level, employers turned to very close substitutes in these service occupations. As Table 9 has shown, the employment level of African-American women had been steadily increasing over most of this time period. Men, of either race, do not appear to be a reasonable or close substitute in these service occupations as we find no evidence for their inflow into this occupation over time.

C. Changes in Perception Regarding African-Americans

There is evidence that the perception of African-Americans has been improving over time. Using the General Social Survey (GSS) data, we found that the responses to survey questions which asked whether African-Americans were hard-working or lazy tended to improve from 1990 to 2000. On a 7 point scale with 1 representing hard-working and 7 representing lazy, there was a slight improvement in pereceptions from 4.357 in 1990 to 4.306 in 1994 and 4.224 in 1996, 4.2 in 1998 and 4.177 in 2000 . Unfortunately, this question was not asked in previous survey waves of the GSS. It is also unfortunate that there are no questions regarding peoples' perceptions on the industriousness of people of darker skin tones in the GSS; this is the closest measure we could find to indicate that there may be societal changes occuring that could possibly explain the observed decrease in importance of skin tone on employment probabilities for African-American women. 


\section{Conclusion}

This research has investigated changes in the effect of skin tone over time on employment probabilities for both men and women. We find that skin tone has diminished in importance over the time period 1985 to 2000 for African-American women. There has been a clear convergence of African-American women employment to that of white women in our sample. We found that the effect of skin tone on employment diminished within the African-American group of women as well; darker skinned African-American women tended to converge in employment probabilities to that of their lighter skinned counterparts. No similar convergence occurred for the men in our sample even when accounting for sample attrition; there is a level difference of approximately 10 percentage points between African-American and white men at each survey year.

Our results, while broadly consistent with Loury (2009), indicate that on at least one dimension African-American women have found improved labor market outcomes. We do not have information on wages or salaries in this data and cannot comment on whether there is continued evidence of a wage gap. Our findings suggest that the expansion of employment opportunities occurred primarily in the low skilled service occupations. Nevertheless, there appears to be a consistent reduction in the importance of skin tone over time for the AfricanAmerican women in our data with respect to employment probabilities.

The findings do not appear to be driven by changes in US welfare programs initiated in the late 1990's. We find that the expansion of employment increased most dramatically for married women in our sample, which is the group that is least likely to be on any welfare assistance. Instead, we find evidence consistent with Autor and Dorn (2009) that there has been an expansion of employment in service occupations. Our results indicate that AfricanAmerican women benefit most from this increase in labor demand in service occupations; we do not find any results for men. We conclude that the expansion in the service occupations over time has benefitted African-American women as they are the closest substitutes to white women in these occupations. In our data, white women were consistently employed at a long-run rate of approximately $60 \%$ which is very close to the US average labor force participation rate for women (of all ages and ethnicities). Therefore, as the demand for 
laborers in the service occupations increased over time and white women were already very near their full employment levels, employers turned to the closest substitute.

\section{References}

[1] Altonji, Joseph and Charles Pierret. 2001. "Employer Learning and Statistical Discrimination." Quarterly Journal of Economics, pp. 313-350.

[2] Arias, Omar and G. Yamada and L. Tejerina. 2004. "Education, Family Background and Racial Earnings Inequality in Brazil." International Journal of Manpower. V. 25 (3): 355-374.

[3] Autor, David H. and David Dorn. 2009. "Inequality and Specialization: The Growth of Low-Skill Service Jobs in the United States" Unpublished Manuscript.

[4] Bayard, Kimberly \& Judith Hellerstein \& David Neumark \& Kenneth Troske, 2003. "New Evidence on Sex Segregation and Sex Differences in Wages from Matched Employee-Employer Data," Journal of Labor Economics, University of Chicago Press, vol. 21(4), pages 887-922, October.

[5] Becker, Gary. 1971. The Economics of Discrimination, 2nd Edition. The University of Chicago Press: Chicago, Il.

[6] Bertrand, Marianne \& Sendhil Mullainathan, 2004."Are Emily and Greg More Employable Than Lakisha and Jamal? A Field Experiment on Labor Market Discrimination," American Economic Review, American Economic Association, vol. 94(4), pages 9911013, September.

[7] Blau, Francine \& Lawrence M. Kahn, 2006. "The U.S. gender pay gap in the 1990s: slowing convergence," Industrial and Labor Relations Review, ILR Review, ILR School, Cornell University, vol. 60(1), pages 45-66, October. 
[8] Blau, Francine D \& Kahn, Lawrence M, 1997."Swimming Upstream: Trends in the Gender Wage Differential in 1980s," Journal of Labor Economics, University of Chicago Press, vol. 15(1), pages 1-42, January.

[9] Bobo, Lawrence, James Johnson, Melvin Oliver, Reynolds Farley, Barry Bluestone, Irene Browne, Sheldon Danziger, Gary Green, Harry Holzer, Maria Krysan, Michael Massagli, Camille Zubrinsky Charles, Joleen Kirschenman, Philip Moss, and Chris Tilly. Multi-City Study of Urban Inequality, 1992-1994: [Atlanta, Boston, Detroit, and Los Angeles] [Computer file]. ICPSR02535-v3. Ann Arbor, MI: Inter-university Consortium for Political and Social Research [distributor], 2000. doi:10.3886/ICPSR02535

[10] Borjas, George, and J. Grogger and G. Hanson. 2010. "Immigratin and theEconomic status of African-American Men." Economica. V 77: 255-282.

[11] Card, David and A. Krueger. 1992. "School Quality and Black-White Relative Earnings: A direct assessment." Quarterly Journal of Economics. 107: 151-200.

[12] Coate, Stephen and G. Loury. 1993. "Will Affirmative-Action Policies Eliminate Negative Stereotypes?" American Economic Review. V. 83 (5): 1220-1240.

[13] Cross, Harry and G. Kenny and J. Mell and W. Zimmerman. 1990. "Employer hiring practices: differential treatment of Hispanic and Anglo job seekers." Urban Institute Press: Washington, DC.

[14] Darity, William A, Jr \& Mason, Patrick L, 1998. "Evidence on Discrimination in Employment: Codes of Color, Codes of Gender," Journal of Economic Perspectives, American Economic Association, vol. 12(2), pages 63-90, Spring.

[15] Espino, Rodolfo and M. Franz. 2002. "Latino Phenotypic Discrimination Revisited: The Impact of Skin Color on Occupational Status." Social Science Quarterly. V. 83 (2) June : 612-623.

[16] de Souza, Melanie M. 2008. "The concept of skin bleaching in Africa and its devastating health implications." Clinics in Dermatology. V. 29, p 27-29. 
[17] Fairlie, Robert. 2009."Can the one-drop rule tell us anything about racial discrimination? New evidence form the multiple race question on the 2000 Census." Labour Economics.

[18] Friedman GD, Cutter GR, Donahue RP, Hughes GH, Hulley SB, Jacobs DR, Jr, Liu K, Savage PJ. CARDIA: Study design, recruitment and some characteristics of the examined subjects. Journal of Clinical Epidemiology. 1988; 41(11):1105-1116. PMID: 3204420 .

[19] General Social Survey website. http://www.norc.org/GSS+Website/ . Public Use Data Catalog. Online Advanced Metadata Search.

[20] Giuliano, Laura \& David I. Levine \& Jonathan Leonard, 2009. "Manager Race and the Race of New Hires," Journal of Labor Economics, University of Chicago Press, vol. 27(4), pages 589-631, October.

[21] Goldin, Claudia \& Katz, Lawrence F, 1996."Technology, Skill, and the Wage Structure: Insights from the Past," American Economic Review, American Economic Association, vol. 86(2), pages 252-57, May.

[22] Goldin, Claudia and Cecilia Rouse.2000. "Orchestrating Impartiality: The Impact Of 'Blind' Auditions On Female Musicians," American Economic Review, v90(4,Sep), 715741.

[23] Goldsmith, Arthur \& Darrick Hamilton \& William Darity, Jr, 2007."From Dark to Light: Skin Color and Wages Among African-Americans," Journal of Human Resources, University of Wisconsin Press, vol. 42(4).

[24] Gottschalk, Peter. 1997. "Inequality, Income Growth and Mobility: the Basic Facts". Journal of Economic Perspectives. Vol. 11 (2), 21-40, Spring.

[25] Gullickson, A. 2005. :The significance of color declines: A Re-analysis of skin tone differentials in post-civil rights America." Social Forces. V. 84 (1): 157-180. 
[26] Halder, Rebat and Pavan Nootheti. 2003. "Ethnic skin disorders overview." Journal of the American Academy of Dermatology. June. S143-S148.

[27] Hersch, Joni. 2008. "Profiling the New Immigrant Worker: The Effects of Skin Color and Height," Journal of Labor Economics, University of Chicago Press, vol. 26(2), pages 345-386, 04.

[28] Hersch, Joni. 2006."Skin-Tone Effects among African Americans: Perceptions and Reality," American Economic Review, American Economic Association, vol. 96(2), pages 251-255, May.

[29] Holzer, Harry and P. Offner and E. Sorensen. 2005. "What explains the continuing decline in labor force activity among young black men?" Labor History. V. 46 (1) : 37-55.

[30] Jackson, James S., and Harold W. Neighbors. National Survey of Black Americans, Waves 1-4, 1979-1980, 1987-1988, 1988-1989, 1992 [Computer file]. ICPSR06668-v1. Ann Arbor, MI: Inter-university Consortium for Political and Social Research [distributor], 1997. doi:10.3886/ICPSR06668

[31] Johnson, James and Elisa Bienstock and Jennifer Stoloff. 1995. "An Empirical Test of Cultural Capital Hypothesis." The Review of Black Political Economy, Spring, vol. 23:4, pp 7-27.

[32] Juhn, Chinhui. 2003. "Labor Market Dropouts and Trends in the Wages of Black and White Men." Industrial and Labor Relations Review. Vol. 56, no. 4, July, pp. 643-62

[33] Juhn, Chinhui. 1992. "The declineof male labor market participation: the role of declining market opportunities." Quarterly Journal of Economics. V. 107: 79-121.

[34] Loury, Linda Datcher, 2009. "Am I still too Black for you?: Schooling and secular change in skin tone effects," Economics of Education Review, Elsevier, vol. 28(4), pages 428-433, August. 
[35] Neal, Derek. 2004."The Measured Black-White Wage Gap among Women Is Too Small," Journal of Political Economy, University of Chicago Press, vol. 112(S1), pages S1-S28, February.

[36] Neal, Derek A \& Johnson, William R, 1996."The Role of Premarket Factors in BlackWhite Wage Differences," Journal of Political Economy, University of Chicago Press, vol. 104(5), pages 869-95, October.

[37] Neumark, David. 1996. "Sex discrimination in restaurant hiring: an audit study." Quarterly Journal of Economics. V 111(3): 915-942.

[38] O’Neill, June. 1990. "The Role of Human Capital in Earnings Differences between Black and White men." Journal of Economic Perspectives. V. 4: 25-45.

[39] O'Neill, June and S. Polachek. 1993. "Why the gender gap in wages narrowed in the 1980s." Journal of Labor Economics. V 11 (1): 205-228.

[40] Mulligan, Casey and Yona Rubinstein. 2008. "Selection, Investment, and Women's Relative Wages Since 1975." Quarterly Journal of Economics. V. 123 (3): 1061-1110.

[41] Turner, Margery. and M. Fix and R. Struyk. 1991. "Opportunities Denied, Opportunities Diminished: Racial Discrimination in hiring." Urban Institute: Washington, DC. 
Table 1: Individual Characteristics for All Survey Years

\begin{tabular}{|c|c|c|c|c|c|c|c|c|}
\hline \multirow[b]{2}{*}{ Variable } & \multicolumn{4}{|c|}{ White Sample } & \multicolumn{4}{|c|}{ African-American Sample } \\
\hline & Mean & Std. Dev. & Min & Max & Mean & Std. Dev. & Min & $\operatorname{Max}$ \\
\hline Full Time Employed & 0.728 & 0.445 & 0 & 1 & 0.671 & 0.470 & 0 & 1 \\
\hline Less Than High School Diploma & 0.015 & 0.122 & 0 & 1 & 0.047 & 0.212 & 0 & 1 \\
\hline High School Diploma & 0.366 & 0.482 & 0 & 1 & 0.622 & 0.485 & 0 & 1 \\
\hline Doctorate Degree & 0.147 & 0.354 & 0 & 1 & 0.031 & 0.174 & 0 & 1 \\
\hline In School & 0.167 & 0.373 & 0 & 1 & 0.173 & 0.378 & 0 & 1 \\
\hline Marital Status & 0.470 & 0.499 & 0 & 1 & 0.342 & 0.474 & 0 & 1 \\
\hline Have Any Kids? & 0.360 & 0.480 & 0 & 1 & 0.528 & 0.499 & 0 & 1 \\
\hline Survey Year 1987 & 0.166 & 0.372 & 0 & 1 & 0.164 & 0.371 & 0 & 1 \\
\hline Survey Year 1990 & 0.170 & 0.375 & 0 & 1 & 0.170 & 0.376 & 0 & 1 \\
\hline Survey Year 1992 & 0.169 & 0.375 & 0 & 1 & 0.170 & 0.376 & 0 & 1 \\
\hline Survey Year 1995 & 0.163 & 0.369 & 0 & 1 & 0.164 & 0.371 & 0 & 1 \\
\hline Survey Year 2000 & 0.163 & 0.370 & 0 & 1 & 0.160 & 0.367 & 0 & 1 \\
\hline Skin Tone - Spectrometer Measure & 53.883 & 4.160 & 43.6 & 85.6 & 77.944 & 7.231 & 49.3 & 92.9 \\
\hline
\end{tabular}

Notes: The table includes percentages, means and standard deviations for individuals from all survey years from CARDIA data set. Sample size is 9672 for whites and 7725 for African-Americans. 
Table 2: Changes in the Effect of Skin Tone on Employment (Years 1- Year 15)

\begin{tabular}{|c|c|c|c|}
\hline & (1) & (2) & (3) \\
\hline Age & $\begin{array}{c}0.00666 \\
(0.00800)\end{array}$ & $\begin{array}{c}0.006 \\
(0.00800)\end{array}$ & $\begin{array}{c}0.00631 \\
(0.00800)\end{array}$ \\
\hline Less than High School & reference & reference & reference \\
\hline High School Diploma & $\begin{array}{l}0.0401^{*} \\
(0.0235)\end{array}$ & $\begin{array}{c}0.0359 \\
(0.0236)\end{array}$ & $\begin{array}{c}0.0363 \\
(0.0236)\end{array}$ \\
\hline Associate's Degree & $\begin{array}{c}0.117 * * * \\
(0.0290)\end{array}$ & $\begin{array}{c}0.114^{* * * *} \\
(0.0290)\end{array}$ & $\begin{array}{c}0.114 * * * \\
(0.0290)\end{array}$ \\
\hline Bachelor's Degree & $\begin{array}{c}0.244 * * * \\
(0.0294)\end{array}$ & $\begin{array}{l}0.242 * * * \\
(0.0294)\end{array}$ & $\begin{array}{c}0.242 * * * \\
(0.0294)\end{array}$ \\
\hline Doctorate Degree & $\begin{array}{c}0.324 * * * \\
(0.0339)\end{array}$ & $\begin{array}{l}0.322 * * * \\
(0.0338)\end{array}$ & $\begin{array}{c}0.323 * * * \\
(0.0339)\end{array}$ \\
\hline In School & $\begin{array}{l}-0.198 * * * \\
(0.00942)\end{array}$ & $\begin{array}{l}-0.199 * * * * \\
(0.00941)\end{array}$ & $\begin{array}{l}-0.198 * * * \\
(0.00942)\end{array}$ \\
\hline Marital Status & $\begin{array}{c}0.0107 \\
(0.00954)\end{array}$ & $\begin{array}{c}0.0106 \\
(0.00954)\end{array}$ & $\begin{array}{c}0.0110 \\
(0.00954)\end{array}$ \\
\hline Any Kids? & $\begin{array}{c}-0.0570^{* * * *} \\
(0.0109)\end{array}$ & $\begin{array}{c}-0.0568 * * * \\
(0.0109)\end{array}$ & $\begin{array}{c}-0.0570^{* * * *} \\
(0.0109)\end{array}$ \\
\hline Household Size & $\begin{array}{c}-0.0348^{* * *} * \\
(0.00328)\end{array}$ & $\begin{array}{c}-0.0347 * * * \\
(0.00328)\end{array}$ & $\begin{array}{c}-0.0346^{* * *} \\
(0.00328)\end{array}$ \\
\hline Year 1 & $\begin{array}{l}0.0973 \\
(0.122)\end{array}$ & $\begin{array}{c}0.378^{* * * *} \\
(0.130)\end{array}$ & $\begin{array}{l}0.274^{*} \\
(0.151)\end{array}$ \\
\hline Year 2 & $\begin{array}{c}0.119 \\
(0.106)\end{array}$ & $\begin{array}{c}0.327 * * * \\
(0.116)\end{array}$ & $\begin{array}{l}0.352^{* *} \\
(0.138)\end{array}$ \\
\hline Year 5 & $\begin{array}{c}0.0908 \\
(0.0822)\end{array}$ & $\begin{array}{l}0.224 * * \\
(0.0943)\end{array}$ & $\begin{array}{l}0.254 * * \\
(0.122)\end{array}$ \\
\hline Year 7 & $\begin{array}{c}0.0704 \\
(0.0662)\end{array}$ & $\begin{array}{l}0.215^{* * * *} \\
(0.0803)\end{array}$ & $\begin{array}{l}0.216^{*} \\
(0.111)\end{array}$ \\
\hline Year 10 & $\begin{array}{c}0.0689 \\
(0.0427)\end{array}$ & $\begin{array}{l}0.157 * * \\
(0.0624)\end{array}$ & $\begin{array}{c}0.123 \\
(0.0999)\end{array}$ \\
\hline Year 15 & reference & reference & reference \\
\hline Black x Year 1 & $\begin{array}{c}-0.140^{* * * *} \\
(0.0197)\end{array}$ & & $\begin{array}{c}-0.0597 \\
(0.0447)\end{array}$ \\
\hline Black x Year 2 & $\begin{array}{c}-0.0905^{* * * *} \\
(0.0198)\end{array}$ & & $\begin{array}{c}0.0145 \\
(0.0450)\end{array}$ \\
\hline Black x Year 5 & $\begin{array}{c}-0.0570 * * * \\
(0.0194)\end{array}$ & & $\begin{array}{c}0.0170 \\
(0.0447)\end{array}$ \\
\hline Black x Year 7 & $\begin{array}{c}-0.0652 * * * \\
(0.0193)\end{array}$ & & $\begin{array}{c}0.000873 \\
(0.0446)\end{array}$ \\
\hline Black x Year 10 & $\begin{array}{c}-0.0446^{* * *} \\
(0.0195)\end{array}$ & & $\begin{array}{l}-0.0196 \\
(0.0451)\end{array}$ \\
\hline Black x Year 15 & reference & & reference \\
\hline Skin Tone $\mathrm{x}$ Year 1 & & $\begin{array}{c}-0.00538 * * * \\
(0.000740)\end{array}$ & $\begin{array}{c}-0.00337 * * \\
(0.00167)\end{array}$ \\
\hline Skin Tone x Year 2 & & $\begin{array}{c}-0.00390 * * * \\
(0.000743)\end{array}$ & $\begin{array}{c}-0.00439 * * * \\
(0.00169)\end{array}$ \\
\hline Skin Tone x Year 5 & & $\begin{array}{c}-0.00251 * * * \\
(0.000726)\end{array}$ & $\begin{array}{l}-0.00308 * \\
(0.00167)\end{array}$ \\
\hline Skin Tone x Year 7 & & $\begin{array}{c}-0.00272 * * * \\
(0.000724)\end{array}$ & $\begin{array}{l}-0.00275^{*} \\
(0.00167)\end{array}$ \\
\hline Skin Tone x Year 10 & & $\begin{array}{c}-0.00170 * * \\
(0.000729)\end{array}$ & $\begin{array}{l}-0.00104 \\
(0.00169)\end{array}$ \\
\hline Skin Tone $\mathrm{x}$ Year 15 & & reference & reference \\
\hline Constant & $\begin{array}{c}0.467 \\
(0.324)\end{array}$ & $\begin{array}{c}0.483 \\
(0.324)\end{array}$ & $\begin{array}{c}0.483 \\
(0.324)\end{array}$ \\
\hline $\begin{array}{l}\text { Number of Obs } \\
\text { R-Squared }\end{array}$ & $\begin{array}{c}17,397 \\
0.095\end{array}$ & $\begin{array}{c}17,397 \\
0.095\end{array}$ & $\begin{array}{c}17,397 \\
0.096\end{array}$ \\
\hline
\end{tabular}


Table 3: Changes in the Effect of Skin Tone on Employment (Years 1- Year 15) for African-American Males and Females

\begin{tabular}{|c|c|c|c|}
\hline & Total & Males & Females \\
\hline & (1) & (2) & (3) \\
\hline \multirow[t]{2}{*}{ Age } & $0.0188 *$ & $0.0392 * * *$ & -0.00808 \\
\hline & $(0.0111)$ & $(0.0144)$ & $(0.0170)$ \\
\hline Less than High School & reference & reference & reference \\
\hline \multirow[t]{2}{*}{ High School Diploma } & 0.0294 & 0.0271 & 0.0422 \\
\hline & $(0.0288)$ & $(0.0393)$ & $(0.0413)$ \\
\hline \multirow[t]{2}{*}{ Associate's Degree } & $0.116^{* * *}$ & 0.0667 & $0.149 * * *$ \\
\hline & $(0.0364)$ & $(0.0534)$ & $(0.0501)$ \\
\hline \multirow[t]{2}{*}{ Bachelor's Degree } & $0.246 * * *$ & $0.270 * * *$ & $0.241 * * *$ \\
\hline & $(0.0400)$ & $(0.0589)$ & $(0.0550)$ \\
\hline \multirow[t]{2}{*}{ Doctorate Degree } & $0.220 * * *$ & $0.264 * * *$ & $0.215 * * *$ \\
\hline & $(0.0539)$ & $(0.0820)$ & $(0.0722)$ \\
\hline \multirow[t]{2}{*}{ In School } & $-0.136 * * *$ & $-0.128 * * *$ & $-0.146^{* * *}$ \\
\hline & $(0.0140)$ & $(0.0231)$ & $(0.0177)$ \\
\hline \multirow[t]{2}{*}{ Marital Status } & $0.0343 * *$ & $0.0836^{* * *}$ & $-9.26 e-05$ \\
\hline & $(0.0142)$ & $(0.0230)$ & $(0.0182)$ \\
\hline \multirow[t]{2}{*}{ Any Kids? } & -0.0163 & $0.0456^{* *}$ & $-0.0801 * * *$ \\
\hline & $(0.0155)$ & $(0.0227)$ & $(0.0216)$ \\
\hline \multirow[t]{2}{*}{ Household Size } & $-0.0200 * * *$ & $-0.0282 * * *$ & $-0.0146^{* *}$ \\
\hline & $(0.00447)$ & $(0.00633)$ & $(0.00623)$ \\
\hline \multirow[t]{2}{*}{ Skin Tone $\mathrm{x}$ Year 1} & $-0.00366^{*}$ & -0.000715 & $-0.00605^{* *}$ \\
\hline & $(0.00203)$ & $(0.00320)$ & $(0.00271)$ \\
\hline \multirow[t]{2}{*}{ Skin Tone x Year 2} & -0.00309 & 0.00261 & $-0.00775^{* * *}$ \\
\hline & $(0.00205)$ & $(0.00320)$ & $(0.00274)$ \\
\hline \multirow[t]{2}{*}{ Skin Tone x Year 5} & -0.00218 & -0.00101 & -0.00355 \\
\hline & $(0.00203)$ & $(0.00320)$ & $(0.00271)$ \\
\hline \multirow[t]{2}{*}{ Skin Tone $\mathrm{x}$ Year 7} & -0.00271 & $-6.65 e-05$ & $-0.00495^{*}$ \\
\hline & $(0.00202)$ & $(0.00319)$ & $(0.00269)$ \\
\hline \multirow[t]{2}{*}{ Skin Tone x Year 10} & -0.000542 & 0.000700 & -0.00243 \\
\hline & $(0.00205)$ & $(0.00322)$ & $(0.00273)$ \\
\hline Skin Tone x Year 15 & reference & reference & reference \\
\hline \multirow[t]{2}{*}{ Constant } & -0.0199 & -0.844 & 1.065 \\
\hline & $(0.444)$ & $(0.574)$ & $(0.677)$ \\
\hline Number of Obs & 7,725 & 3,107 & 4,618 \\
\hline R-Squared & 0.081 & 0.095 & 0.085 \\
\hline
\end{tabular}

Notes: The table reports change of the effect of skin tone on employment for African Americans.

Clustered standard errors by individual are reported in parentheses. Regressions control for schooling indicators; age and age square; married, in school and having children dummies; number of children and individual fixed effects. $* * * \mathrm{p}<0.01, * * \mathrm{p}<0.05, * \mathrm{p}<0.1$ 
Table 4: Changes in the Effect of Skin Tone on Employment (Years 1- Year 15) for white Males and Females

\begin{tabular}{|c|c|c|c|}
\hline & Total & Males & Females \\
\hline & (1) & (2) & (3) \\
\hline \multirow[t]{2}{*}{ Age } & -0.00268 & -0.00616 & 0.0106 \\
\hline & $(0.0115)$ & $(0.0138)$ & $(0.0180)$ \\
\hline Less than High School & reference & reference & reference \\
\hline \multirow[t]{2}{*}{ High School Diploma } & $0.0719 *$ & 0.0530 & 0.106 \\
\hline & $(0.0419)$ & $(0.0490)$ & $(0.0676)$ \\
\hline \multirow[t]{2}{*}{ Associate's Degree } & $0.139 * * *$ & $0.118^{*}$ & $0.186^{* *}$ \\
\hline & $(0.0493)$ & $(0.0607)$ & $(0.0765)$ \\
\hline \multirow[t]{2}{*}{ Bachelor's Degree } & $0.259 * * *$ & $0.203 * * *$ & $0.318 * * *$ \\
\hline & $(0.0475)$ & $(0.0573)$ & $(0.0745)$ \\
\hline \multirow[t]{2}{*}{ Doctorate Degree } & $0.363 * * *$ & $0.320 * * *$ & $0.386 * * *$ \\
\hline & $(0.0516)$ & $(0.0628)$ & $(0.0800)$ \\
\hline \multirow[t]{2}{*}{ In School } & $-0.249 * * *$ & $-0.279 * * *$ & $-0.230 * * *$ \\
\hline & $(0.0126)$ & $(0.0167)$ & $(0.0179)$ \\
\hline \multirow[t]{2}{*}{ Marital Status } & -0.00984 & $0.0469 * * *$ & $-0.0779 * * *$ \\
\hline & $(0.0128)$ & $(0.0172)$ & $(0.0181)$ \\
\hline \multirow[t]{2}{*}{ Any Kids? } & $-0.0844 * * *$ & $0.0630 * * *$ & $-0.229 * * *$ \\
\hline & $(0.0154)$ & $(0.0203)$ & $(0.0221)$ \\
\hline \multirow[t]{2}{*}{ Household Size } & $-0.0495 * * *$ & $-0.0331 * * *$ & $-0.0727 * * *$ \\
\hline & $(0.00487)$ & $(0.00615)$ & $(0.00722)$ \\
\hline \multirow[t]{2}{*}{ Skin Tone x Year 1} & -0.00120 & 0.00197 & 0.00101 \\
\hline & $(0.00302)$ & $(0.00392)$ & $(0.00447)$ \\
\hline \multirow[t]{2}{*}{ Skin Tone x Year 2} & $-0.00592 *$ & -0.00468 & -0.00279 \\
\hline & $(0.00303)$ & $(0.00393)$ & $(0.00450)$ \\
\hline \multirow[t]{2}{*}{ Skin Tone x Year 5} & -0.00456 & $-0.00676^{*}$ & -0.00163 \\
\hline & $(0.00301)$ & $(0.00390)$ & $(0.00447)$ \\
\hline \multirow{2}{*}{ Skin Tone x Year 7} & -0.00233 & -0.00437 & -0.000681 \\
\hline & $(0.00301)$ & $(0.00390)$ & $(0.00447)$ \\
\hline \multirow{2}{*}{ Skin Tone x Year 10} & -0.00200 & -0.00288 & -0.000604 \\
\hline & $(0.00305)$ & $(0.00394)$ & $(0.00453)$ \\
\hline Skin Tone x Year 15 & reference & reference & reference \\
\hline \multirow[t]{2}{*}{ Constant } & $0.841^{*}$ & $1.007 *$ & 0.317 \\
\hline & $(0.471)$ & $(0.564)$ & $(0.739)$ \\
\hline Number of Obs & 9,672 & 4,636 & 5,036 \\
\hline R-Squared & 0.121 & 0.165 & 0.164 \\
\hline
\end{tabular}

Notes: The table reports change of the effect of skin tone on employment for white sample. Clustered standard errors by individual are reported in parentheses. Regressions control for schooling indicators; age anda ge square; married, in school and having children dummies; number of children and individual fixed effects. $* * * \mathrm{p}<0.01, * * \mathrm{p}<0.05, * \mathrm{p}<0.1$ 
Table 5: Changes in the Effect of Skin Tone on Employment (Years 1- Year 15) Females

\begin{tabular}{|c|c|}
\hline Age & $\begin{array}{l}-0.00718 \\
(0.0124)\end{array}$ \\
\hline Less than High School & reference \\
\hline High School Diploma & $\begin{array}{c}0.0456 \\
(0.0354)\end{array}$ \\
\hline Associate's Degree & $\begin{array}{c}0.144 * * * \\
(0.0419)\end{array}$ \\
\hline Bachelor's Degree & $\begin{array}{c}0.262 * * * \\
(0.0428)\end{array}$ \\
\hline Doctorate Degree & $\begin{array}{c}0.306 * * * \\
(0.0490)\end{array}$ \\
\hline In School & $\begin{array}{c}-0.190 * * * \\
(0.0127)\end{array}$ \\
\hline Marital Status & $\begin{array}{c}-0.0406 * * * \\
(0.0129)\end{array}$ \\
\hline Any Kids? & $\begin{array}{c}-0.171 * * * \\
(0.0154)\end{array}$ \\
\hline Household Size & $\begin{array}{c}-0.0418 * * * \\
(0.00473)\end{array}$ \\
\hline Skin Tone x Year 1 & $\begin{array}{c}-0.00764 * * * \\
(0.00106)\end{array}$ \\
\hline Skin Tone x Year 2 & $\begin{array}{c}-0.00665^{* * *} \\
(0.00106)\end{array}$ \\
\hline Skin Tone x Year 5 & $\begin{array}{c}-0.00341 * * * \\
(0.00103)\end{array}$ \\
\hline Skin Tone $\mathrm{x}$ Year 7 & $\begin{array}{c}-0.00392 * * * \\
(0.00103)\end{array}$ \\
\hline Skin Tone x Year 10 & $\begin{array}{c}-0.00337 * * * \\
(0.00104)\end{array}$ \\
\hline Skin Tone x Year 15 & reference \\
\hline Constant & $\begin{array}{l}1.063 * * \\
(0.502)\end{array}$ \\
\hline $\begin{array}{l}\text { Number of Obs } \\
\text { R-Squared }\end{array}$ & $\begin{array}{l}9,654 \\
0.112\end{array}$ \\
\hline
\end{tabular}

Notes: The table reports change of the effect of skin tone on employment for females. Clustered standard errors by individual are reported in parentheses. Regressions control for schooling indicators; age and age square; married, in school and having children dummies; number of children and individual fixed effects. $* * * \mathrm{p}<0.01, * * \mathrm{p}<0.05, * \mathrm{p}<0.1$ 
Table 6: Changes in the Effect of Skin Tone on Employment (Years 1- Year 15) Males

\begin{tabular}{|c|c|}
\hline$\overline{\text { Age }}$ & $\begin{array}{c}0.0179 * \\
(0.00986)\end{array}$ \\
\hline Less than High School & reference \\
\hline High School Diploma & $\begin{array}{c}0.0326 \\
(0.0299)\end{array}$ \\
\hline Associate's Degree & $\begin{array}{l}0.0758 * \\
(0.0391)\end{array}$ \\
\hline Bachelor's Degree & $\begin{array}{c}0.219 * * * \\
(0.0388)\end{array}$ \\
\hline Doctorate Degree & $\begin{array}{c}0.323 * * * \\
(0.0450)\end{array}$ \\
\hline In School & $\begin{array}{c}-0.221 * * * \\
(0.0136)\end{array}$ \\
\hline Marital Status & $\begin{array}{c}0.0626 * * * \\
(0.0138)\end{array}$ \\
\hline Any Kids? & $\begin{array}{c}0.0565^{* * *} * \\
(0.0150)\end{array}$ \\
\hline Household Size & $\begin{array}{c}-0.0308 * * * \\
(0.00436)\end{array}$ \\
\hline Skin Tone x Year 1 & $\begin{array}{l}-0.00170 * \\
(0.000992)\end{array}$ \\
\hline Skin Tone $\mathrm{x}$ Year 2 & $\begin{array}{c}2.54 \mathrm{e}-05 \\
(0.000997)\end{array}$ \\
\hline Skin Tone $\mathrm{x}$ Year 5 & $\begin{array}{c}-0.00102 \\
(0.000973)\end{array}$ \\
\hline Skin Tone x Year 7 & $\begin{array}{c}-0.00100 \\
(0.000973)\end{array}$ \\
\hline Skin Tone x Year 10 & $\begin{array}{c}0.000273 \\
(0.000977)\end{array}$ \\
\hline Skin Tone x Year 15 & reference \\
\hline Constant & $\begin{array}{c}0.0197 \\
(0.400)\end{array}$ \\
\hline $\begin{array}{l}\text { Number of Obs } \\
\text { R-Squared }\end{array}$ & $\begin{array}{l}7,743 \\
0.127\end{array}$ \\
\hline \multicolumn{2}{|c|}{$\begin{array}{l}\text { Notes: The table reports change of the effect of skin tone on } \\
\text { employment for males. Clustered standard errors by individual are } \\
\text { reported in parentheses. Regressions control for schooling } \\
\text { indicators; age and age square; married, in school and having } \\
\text { children dummies; number of children and individual fixed effects } \\
* * * p<0.01, * * p<0.05, * p<0.1\end{array}$} \\
\hline
\end{tabular}


Table 7 : Skin Tone Effects on Employment by Marital Status in Last Two Survey Years

\begin{tabular}{lcccc}
\hline \hline & \multicolumn{4}{c}{ African-American Females } \\
\cline { 2 - 6 } & \multicolumn{2}{c}{ Unmarried } & \multicolumn{2}{c}{ Married } \\
Skin Tone x Year 1 & -0.004 & 0.003 & -0.011 & 0.004 \\
Skin Tone x Year 2 & -0.007 & 0.003 & -0.011 & 0.004 \\
Skin Tone x Year 5 & -0.001 & 0.003 & -0.011 & 0.004 \\
Skin Tone x Year 7 & -0.005 & 0.003 & -0.009 & 0.004 \\
Skin Tone x Year 10 & -0.002 & 0.003 & -0.006 & 0.004 \\
Skin Tone x Year 15 & \multicolumn{2}{c}{ reference } & \multicolumn{2}{c}{ reference } \\
Number of Obs & \multicolumn{2}{c}{3240} & \multicolumn{2}{c}{2283} \\
\hline \hline
\end{tabular}

Notes: The table reports change of the effect of skin tone on employment for African Americans by marital status.

Clustered standard errors by individual are reported in parentheses. Regressions control for schooling indicators; age and age square; in school and having children dummies; individual fixed effects. $* * * p<0.01,{ }^{*} \mathrm{p}<0.05,{ }^{*} \mathrm{p}<0.1$ 
Table 8: Changes in the Effect of Skin Tone on Employment (Years 1- Year 15) in Different Industries by Gender

\begin{tabular}{|c|c|c|c|c|c|c|c|c|c|c|}
\hline \multirow[b]{3}{*}{ Skin Tone x Year 1} & \multicolumn{2}{|c|}{ Professional } & \multicolumn{2}{|c|}{ Sales } & \multicolumn{2}{|c|}{ Services } & \multicolumn{2}{|c|}{ Precision Production } & \multicolumn{2}{|c|}{ Labor } \\
\hline & \multicolumn{10}{|c|}{ Panel A: Females } \\
\hline & -0.001 & 0.001 & -0.001 & 0.001 & -0.003 & 0.001 & 0.000 & 0.000 & 0.000 & 0.000 \\
\hline Skin Tone x Year 2 & -0.001 & 0.001 & -0.001 & 0.001 & -0.002 & 0.001 & 0.000 & 0.000 & 0.000 & 0.000 \\
\hline Skin Tone x Year 5 & -0.001 & 0.001 & 0.000 & 0.001 & -0.001 & 0.001 & 0.000 & 0.000 & 0.000 & 0.000 \\
\hline Skin Tone x Year 7 & 0.000 & 0.001 & -0.001 & 0.001 & -0.002 & 0.001 & 0.000 & 0.000 & 0.001 & 0.000 \\
\hline Skin Tone x Year 10 & -0.004 & 0.001 & 0.001 & 0.001 & -0.001 & 0.001 & 0.000 & 0.000 & 0.000 & 0.000 \\
\hline Skin Tone x Year 15 & \multicolumn{2}{|c|}{ reference } & \multicolumn{2}{|c|}{ reference } & \multicolumn{2}{|c|}{ reference } & \multicolumn{2}{|c|}{ reference } & \multicolumn{2}{|c|}{ reference } \\
\hline \multirow[t]{2}{*}{ Number of Obs } & \multicolumn{2}{|c|}{9655} & \multicolumn{2}{|c|}{9655} & \multicolumn{2}{|c|}{9655} & \multicolumn{2}{|c|}{9655} & \multicolumn{2}{|c|}{9655} \\
\hline & \multicolumn{10}{|c|}{ Panel B: Males } \\
\hline Skin Tone x Year 1 & 0.001 & 0.001 & 0.001 & 0.001 & -0.001 & 0.001 & 0.000 & 0.001 & -0.001 & 0.001 \\
\hline Skin Tone x Year 2 & 0.000 & 0.001 & 0.001 & 0.001 & 0.000 & 0.001 & 0.001 & 0.001 & -0.001 & 0.001 \\
\hline Skin Tone x Year 5 & -0.001 & 0.001 & 0.001 & 0.001 & 0.000 & 0.001 & 0.000 & 0.001 & 0.001 & 0.001 \\
\hline Skin Tone x Year 7 & 0.000 & 0.001 & 0.001 & 0.001 & 0.000 & 0.001 & 0.000 & 0.001 & 0.000 & 0.001 \\
\hline Skin Tone x Year 10 & 0.000 & 0.001 & 0.000 & 0.001 & 0.001 & 0.001 & 0.000 & 0.001 & 0.000 & 0.001 \\
\hline Skin Tone x Year 15 & \multicolumn{2}{|c|}{ reference } & \multicolumn{2}{|c|}{ reference } & \multicolumn{2}{|c|}{ reference } & \multicolumn{2}{|c|}{ reference } & \multicolumn{2}{|c|}{ reference } \\
\hline Number of Obs & \multicolumn{2}{|c|}{7743} & \multicolumn{2}{|c|}{7743} & \multicolumn{2}{|c|}{7743} & \multicolumn{2}{|c|}{7743} & \multicolumn{2}{|c|}{7743} \\
\hline
\end{tabular}

Notes: The table reports change of the effect of skin tone on different occupations for African Americans by gender. Clustered standard errors by individual are reported in parenthesis.

Regressions control for schooling indicators; age and its square; a marriage, in school and having children dummies; and individual fixed effects. $* * * \mathrm{p}<0.01, * * \mathrm{p}<0.05, * \mathrm{p}<0.1$ 
Table 9 : Full-Time Employment Probabilities by Gender and Ethnicity

\begin{tabular}{|c|c|c|c|c|}
\hline & \multicolumn{2}{|c|}{ Women } & \multicolumn{2}{|c|}{ Men } \\
\hline & African-American & White & African-American & $\underline{\text { White }}$ \\
\hline Employment Probability, Survey Wave 1 & 49 & $\overline{62}$ & 57 & 71 \\
\hline Employment Probability, Survey Wave 2 & 61 & 67 & 70 & 78 \\
\hline Employment Probability, Survey Wave 3 & 66 & 64 & 72 & 85 \\
\hline Employment Probability, Survey Wave 4 & 65 & 63 & 73 & 85 \\
\hline Employment Probability, Survey Wave 5 & 68 & 65 & 79 & 89 \\
\hline Employment Probability, Survey Wave 6 & 74 & 59 & 77 & 89 \\
\hline
\end{tabular}

Notes: The table presents percentage of employment for individuals by race and gender from all survey years from CARDIA data set. 
Figure 1: Skin Tone Distribution by Race

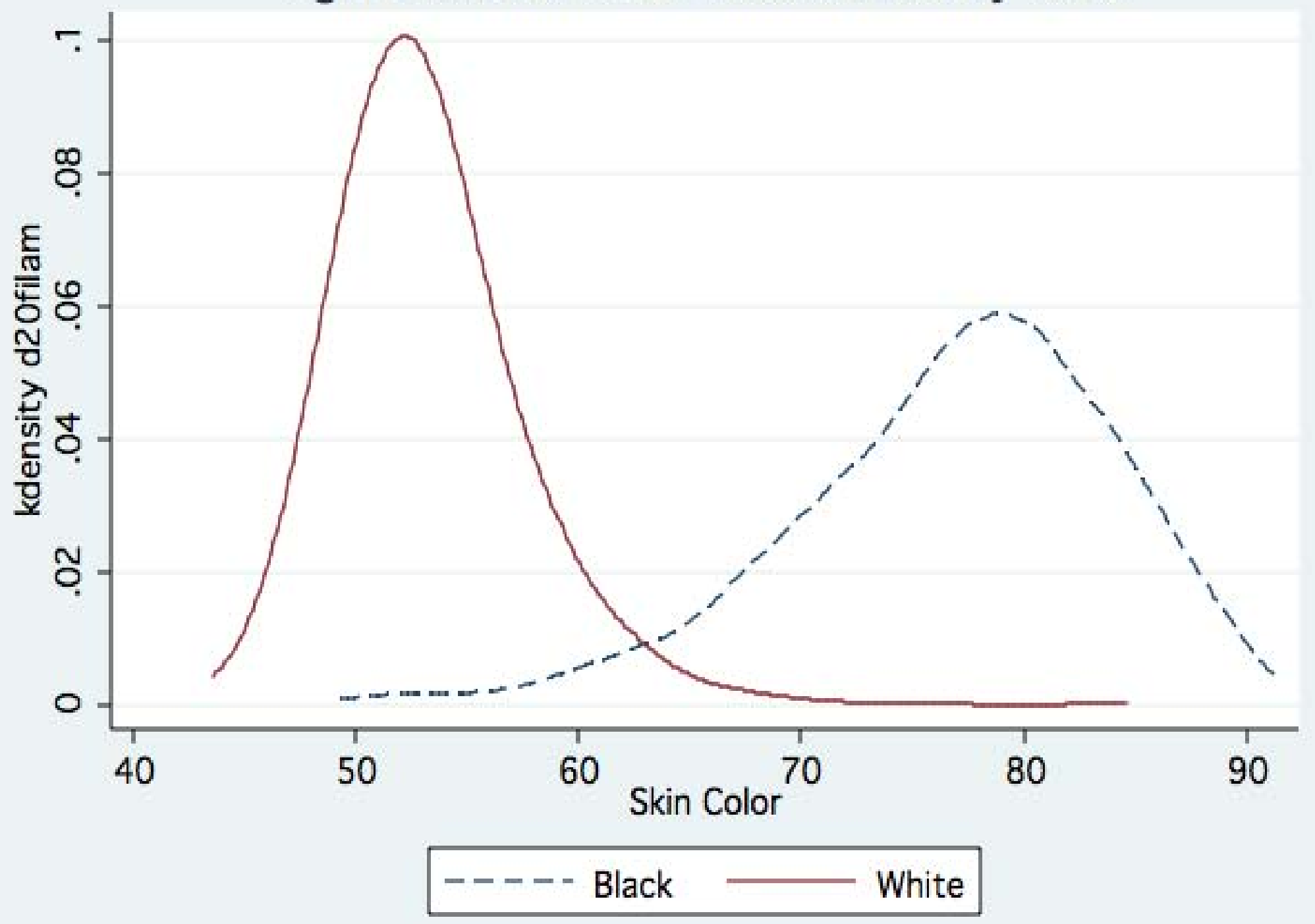



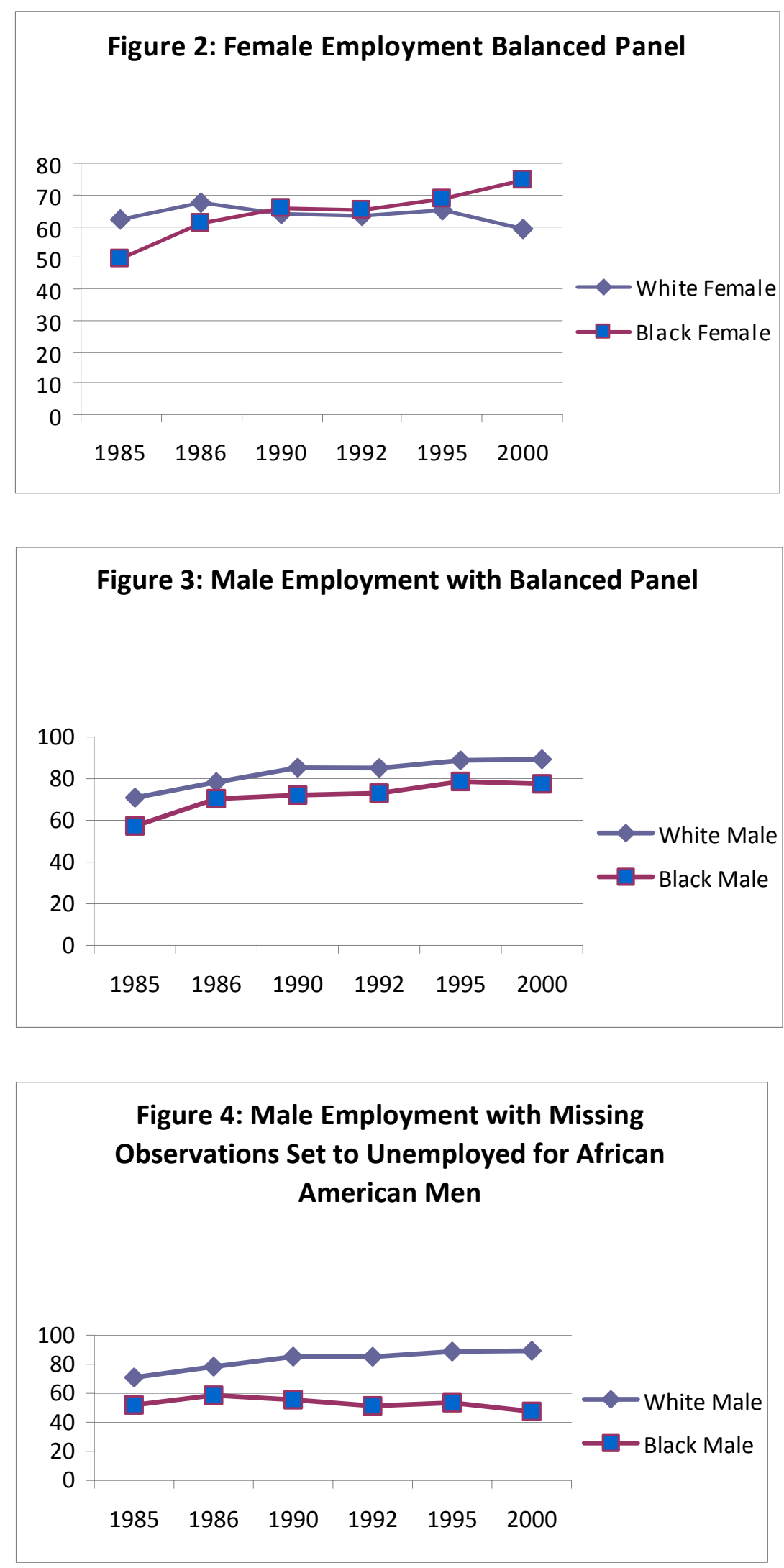
Appendix Table I: Probit Regression of Employment on Skin Tone and Household Characteristics using the National Survey of Black Americans, 1979-1980 Wave

\begin{tabular}{lc}
\hline \hline & \\
& Probability of Employment, \\
Skin Tone & Women \\
\cline { 2 - 2 } Older Age Cohort & 0.017 \\
& $(0.033)$ \\
Skin Tone x Older Age Cohort & -0.165 \\
& $(0.156)$ \\
Number of Observations & 0.035 \\
Pseudo R Squared & $(0.045)$ \\
\hline \hline
\end{tabular}

Notes: Skin Tone takes on 5 values: Very Dark Brown, Dark Brown, Medium Brown, Light Brown, and Very Light Brown. Higher numeric values indicated lighter skin tone. Standard errors clustered on age. Older Age cohort is ages 40-55; younger age cohort is ages 25-39 and is the reference category. Additional controls include number of children in household, age, education in years, household size and marital status. 
Appendix Table II: Probit Regression of Employment on Skin Tone and Household Characteristics using the National Survey of Black Americans, 1987-1988 Wave

Skin Tone

Probability of Employment,

Women

Older Age Cohort

0.011

$(0.025)$

0.215

$(0.333)$

Number of Children in Household

$-0.005$

$(0.009)$

Number of Observations

389

Pseudo R Squared

0.053

Note: Skin Tone takes on 5 values: Very Dark Brown, Dark Brown, Medium Brown, Light Brown, and Very Light Brown. Higher numeric values indicated lighter skin tone. Standard errors clustered on age. Older Age cohort is ages 40-55; younger age cohort is ages 25-39 and is the reference category. Additional controls include number of children in household, age, education in years, household size and marital status. 


\section{Appendix Table III: Probit Regression of Employment on Skin Tone and Household Characteristics using the Multi-City Study of Urban Inequality, 1992}

Skin Tone

Probability of Employment, African-American Women

Older Age Cohort

$(0.022)$

$(0.133)$

Skin Tone x Older Age Cohort

$-0.066$

(0.049)

Number of Observations

1355

Pseudo R Squared

0.066

Note: Skin Tone takes on 3 values: Dark, Medium, Light. Higher numeric values indicated lighter skin tone. Standard errors clustered on age. Older Age cohort is ages 4055; younger age cohort is ages 25-39 and is the reference category. Additional controls include number of children in household, age, education in years, household size and marital status. 